\title{
Levels of stress and dispositional optimism among patients hospitalized in cardiology departments
}

\section{Stres i dyspozycyjny optymizm wśród pacjentów hospitalizowanych na oddziałach kardiologicznych}

\author{
Katarzyna Białek \\ Institute of Medical Sciences, Jan Kochanowski University, Collegium Medicum, Kielce, Poland
}

Medical Studies/Studia Medyczne 2021; 37 (1): 25-32

DOI: https://doi.org/10.5114/ms.2021.104997

Key words: stress, dispositional optimism, cardiovascular disease, cardiac units, health.

Słowa kluczowe: stres, dyspozycyjny optymizm, choroby układu krążenia, oddział kardiologii, zdrowie.

\begin{abstract}
Introduction: In cardiovascular diseases attention is drawn to the importance of the impact of the individual's personal resources in coping with stress related to adaptation to the disease. One of them is dispositional optimism, the essence of which is positive perception of the disease situation.

Aim of the research: To define the connection between the level of stress and dispositional optimism among people with cardiovascular disease.

Material and methods: The study was conducted on a group of 104 patients hospitalized in cardiology units. The selfdesigned questionnaire, the Scale of Perceived Stress - PSS-10, and the Life Orientation Test-Revised - LOT-R were used to carry out the study.

Results: In $89.42 \%$ of investigated patients the level of experienced stress was defined as high. The most stressful predictors during hospitalization were related to fear of a sudden attack of the disease and unexpected hospitalization (61.54\%), chronic fatigue (56.73\%), lack of psychological support (50.96\%), depressed mood (50.96\%), maintaining a diet (48.08\%), and limiting physical activity $(48.08 \%)$. The studied group had an extremely pessimistic approach $(57.69 \%)$. There was a connection between the level of stress and dispositional optimism among members of the tested group $(p<0.001)$.

Conclusions: The results of the study indicate the need for involvement of psychological support of hospitalized patients on the impact of health and the effectiveness of attitude to disease. Special attention should be paid to personal resources of patients, especially dispositional optimism.
\end{abstract}

\section{Streszczenie}

Wprowadzenie: W chorobach układu krążenia zwraca się uwagę na znaczenie zasobów osobistych jednostki w radzeniu sobie ze stresem i adaptacji do choroby. Jednym z nich jest dyspozycyjny optymizm, którego istotą jest pozytywne postrzeganie sytuacji choroby i związanego z nią przebiegu procesu terapeutycznego.

Cel pracy: Określenie związku między poziomem stresu a dyspozycyjnym optymizmem u pacjentów leczonych z powodu chorób układu krążenia.

Materiał i metody: Badanie przeprowadzono u 104 pacjentów hospitalizowanych na oddziałach kardiologicznych. Do oceny stopnia nasilenia stresu wykorzystano Skale odczuwanego stresu - PSS-10, z kolei do oceny poziomu dyspozycyjnego optymizmu Test orientacji życiowej - LOT-R.

Wyniki: U 89,42\% pacjentów poziom odczuwanego stresu określono jako wysoki. Najbardziej stresującymi czynnikami podczas hospitalizacji okazały się lęk przed nagłym atakiem choroby i nieoczekiwaną kolejną hospitalizacją (61,54\%), chroniczne zmęczenie (56,73\%), brak wsparcia psychologicznego (50,96\%), obniżony nastrój (57,69\%), utrzymanie diety $(48,08 \%)$ i ograniczenie aktywności fizycznej (48,08\%). Badani zadeklarowali skrajnie pesymistyczne nastawienie (57,69\%). Wykazano, że istnieje związek między poziomem stresu a dyspozycyjnym optymizmem w badanej grupie $(p<0,001)$.

Wnioski: Wyniki badań wskazują na potrzebę psychologicznego wsparcia hospitalizowanych pacjentów w zakresie zmiany postawy wobec choroby. Szczególną uwagę należy zwrócić na zasoby radzenia sobie z aktualną sytuacją zdrowotną leczonych chorych, w tym poziom dyspozycyjnego optymizmu. 


\section{Introduction}

Despite the ever-increasing survival rates, cardiovascular diseases are still life-threatening and cause 17 million deaths annually [1]. Many of them, e.g. acute coronary syndromes (ACS) or heart failure (HF), have extremely stressful characteristics. These include the suddenness of disease, real danger of death, and a feeling of helplessness and loss of control over the situation. All this can lead to strong stressful reactions. The fear is aroused not only by the heart disease itself, but also by its consequences in the form of disability or death. Alonzo [2] adds that invasive and life-saving procedures, e.g. angioplasty, angiography, and cardioverter implantation, as well as the adverse effects of the applied pharmacotherapy may also be potentially traumatic events leading to the development of post-traumatic stress disorder (PTSD).

Cardiac wards hospitalize patients with acute coronary syndromes, pulmonary embolism, acute or chronic heart failure, life-threatening or clinically significant arrhythmia and/or conduction disorders, after sudden cardiac arrest and in others who have indications for special cardiological care. These are usually emergency situations and may result in serious damage to body functions, even loss of life. Patients are then exposed to high levels of stress and a number of psychological complications, which play a special role in cardiac prognosis. Depression, for instance, is prospectively associated with both the newly emerging cardiovascular disease and cardiovascular mortality, irrespective of traditional cardiovascular risk factors [3].

Therefore, the individual characteristics of a patient are important in the process of coping with the disease. Among numerous personal resources that are significant for health, particular attention was paid to the role of a positive attitude towards the treatment and healing process, which Scheier and Carver [4] named dispositional optimism. According to them, it is rather a constant characteristic of the personality, which induces motivation, perseverance, and determination in achieving goals and expecting positive events in the future.

According to the literature, patients with optimistic attitudes cope better with the disease situation compared to patients with pessimistic orientation [5]. Moreover, positive effects of optimism with respect to the immune system were observed. However, the positive effects of dispositional optimism were particularly beneficial in patients with cardiovascular diseases [6]. The optimistic attitude was associated with markedly lower arterial blood pressure values and lower pressure increases in stressful situations [7]. Optimism is also associated with lower percentages of sudden cardiovascular deaths and/ or cardiac mortality $[8,9]$.

\section{Aim of the research}

The aim of the study was to determine the intensity of perceived stress and dispositional optimism in patients treated in cardiology departments.

\section{Material and methods}

The study involved 104 patients hospitalized at the Świętokrzyskie Centre of Cardiology from July to October 2019. Each patient agreed to participate in the study. In total 112 questionnaires were distributed. Eight questionnaires were rejected due to incomplete filling in of sheets. Two people refused to participate in the study.

To collect the data the author's survey was used, which included single-choice questions about sociometric data, such as gender, age, education, marital status, place and method of residence, length of treatment, comorbidities, and the number of hospitalizations. Patients were also asked to choose what is most difficult for them in their illness during hospitalization in the cardiology department. A list of 18 factors was proposed as multiple-choice questions, which was developed on the basis of literature and interviews with physicians on the general well-being of treated patients. The analysis of these variables was performed by calculating the number and percentage of occurrences of each value.

The stress level in the study group was determined using the Perceived Stress Scale (PSS-1) by Cohen, Kamarck, and Mermelstein [10] in the Polish adaptation of Juczyński and Ogińska-Bulik [11]. The questionnaire contains 10 questions, which refer to the assessment of the intensity of stress related to one's life situation during the preceding month. The overall score of the scale is the sum of all points from 0 to 40 . The answers were grouped according to the point value (0-4), where 0 means 'never' and 4 means 'very often'. The higher the score, the greater the intensity of the stress experienced. For PSS-10 there are sten-standards that allow the interpretation of the scores. The most common assumption is that stens 5 and 6 are average, stens 7-10 are high, and stens 1-4 are low. The PSS-10 has good psychometric properties for which Cronbach's $\alpha$ is 0.86 .

In order to verify the level of optimism, the Life Orientation Test-Revised (LOT-R) by Scheier, Carver, and Bridges [12] in the Polish adaptation of Poprawa and Juczyński [13] was used. The scale contains 10 statements, of which 6 assess the level of dispositional optimism. The test result is therefore the sum of 6 statements. The numbers 1, 4, and 10 are positive statements and 3, 7, and 9 are negative statements. Questions are answered on a 5-point scale, where 0 means "definitely not applicable to me" and 4 means "definitely applicable to me". The overall test score is between 0 and 24 points. The range $0-12$ points indi- 
cates a low level of optimism, 13-16 indicates an average level of optimism, and a score between 17 and 24 indicates a high level of dispositional optimism. Therefore, the higher the score, the higher the level of optimism. LOT-R's internal compliance was determined on the basis of Cronbach's $\alpha$, which is 0.76 .

\section{Statistical analysis}

It was also examined whether individual variables such as gender, age, education, place of residence, length of treatment, incidence of comorbidities, and number of hospitalizations affect the level of stress. The values of quantitative variables were compared in 2 groups using the Mann-Whitney $U$ test, and in 3 or more groups using the Kruskal-Wallis test. Correlations between quantitative variables were analysed using the Spearman correlation coefficient.

Statistical analyses were performed using the $\mathrm{R}$ program, version 3.6.1 [14]. The analysis adopted the significance level of 0.05 ; therefore, all $p$-values below 0.05 were interpreted as indicating significant relationships.

\section{Results}

The study involved 104 patients, including 64 men and 40 women aged 24 to 90 years. The average age was $68.42 \pm 11.75$ years. The most numerous group comprised patients aged $61-70$ years $(n=38 ; 36.54 \%)$, the majority of whom were married and/or in an informal partnership ( $n=76 ; 73.08 \%$ ). The highest percentage of respondents were living on retirement and/or disability pensions $(n=80 ; 76.92 \%)$. Most of them were people with secondary education $(n=74$; $71.15 \%)$ and residents of a large city of up to 50,000 residents ( $n=50 ; 48.08 \%)$. Only 34 (32.69\%) people lived in the countryside. The average length of treatment was $9.39 \pm 8.35$ years and ranged from 3 days to 50 years. The most numerous group comprised patients treated from 0 to 10 years $(n=70 ; 67.31 \%)$, followed by those who were ill from 11 to 20 years $(n=29$; $27.88 \%)$, then from 21 to 30 years $(n=4 ; 3.85 \%)$. Only 1 person indicated the range from 41 to 50 years.

Patients were treated in the ward for various cardiac diseases, such as heart failure, myocardial infarction, ischaemic heart disease, atrial fibrillation and flutter, atherosclerosis, angina pectoris, atrioventricular block, heart cancer, pulmonary embolism, or premature ventricular depolarization. These conditions were classified into 4 categories. The first were patients with ischaemic heart disease and other forms of atherosclerosis, i.e. coronary heart disease, myocardial infarction, atherosclerosis, angina pectoris (I.25.1; I.25.8; I.25.9; I.21.1; I.21.4; I.21.9 ; I.25.0; I.25.1; I.70.2; I.20.9). The second was defined as arrhythmia, which included patients with atrioventricular block, sinus syndrome, premature atrial depolarization, paroxysmal tachycardia, and atrial fibrillation and flutter
Table 1. Clinical characteristics of the examined group (categories of disease groups and comorbidities)

\begin{tabular}{|lcc|}
\hline $\begin{array}{l}\text { The main diagnosis - categories } \\
\text { of disease groups }\end{array}$ & $\mathbf{N}$ & $\%$ \\
$\begin{array}{l}\text { Ischaemic heart disease and other } \\
\text { forms of atherosclerosis }\end{array}$ & 47 & 45.19 \\
Heart failure and valvular defects & 33 & 31.73 \\
Arrhythmias & 17 & 16.35 \\
Other acute conditions & 7 & 6.73 \\
Diabetes mellitus & 23 & 22.12 \\
Cancer & 5 & 4.81 \\
Epilepsy & 4 & 3.85 \\
Depression & 3 & 2.88 \\
$\begin{array}{l}\text { Hypothyroidism, Hashimoto's } \\
\text { thyroiditis }\end{array}$ & 3 & 2.88 \\
Stroke & 3 & 2.88 \\
$\begin{array}{l}\text { Chronic obstructive pulmonary } \\
\text { disease }\end{array}$ & 2 & 1.92 \\
Buerger's disease & 1 & 0.96 \\
Parkinson's disease & 1 & 0.96 \\
\hline
\end{tabular}

(I.44.1; I.44.2; I.49.5; I.49.9; I.4.48). The third category included patients treated for heart failure and valvular disease (I.50.0; I.35.1). The fourth comprised other acute conditions, i.e. patients treated for atrial septal defect, cardiogenic shock, pulmonary embolism, and acute endocarditis (Q.21.1; R.57.0; I.26.0; I.33.9). The most numerous group was made up of patients with heart failure (30.77\%), myocardial infarction (22.12\%), and ischaemic heart disease $(9.62 \%)$. When analysing co-morbidities, the most common were diabetes $(22.12 \%)$, cancer $(4.81 \%)$, epilepsy $(3.85 \%)$, depression $(2.88 \%)$, and stroke $(2.88 \%)$. The clinical characteristics of the patients treated are presented in Table 1.

Taking into account the number of hospitalizations during the year, almost half of the patients ( $n=44 ; 42.31 \%)$ were hospitalized $0-2$ times, and $40(38.46 \%)$ people $3-4$ times. The average number of hospitalizations was $3.08 \pm 1.86$. Most patients $(n=50$; $48.08 \%$ ) were hospitalized for 6 to 10 days, then up to 5 days $(n=40 ; 38.46 \%)$. One person stayed in the ward for the longest, up to 45 days. The average length of hospitalization was $7.25 \pm 4.78$ days and ranged from 2 to 43 days.

Fear of sudden disease attack and unexpected hospitalization (61.54\%), chronic fatigue (56.73\%), lack of psychological care during hospitalization (50.96\%), decreased mood resulting from the disease (50.96\%), maintenance of proper diet (48.08\%), and limitations of physical activity and sports activities (48.08\%) were noted as the most stressful factors in the study group. The above values are classified in Table 2 . 
Table 2. The most stressful factors in the group of patients treated in the cardiology department

\begin{tabular}{|lcc|}
\hline $\begin{array}{l}\text { What is most stressful during } \\
\text { hospitalization in the cardiology } \\
\text { department? }\end{array}$ & $N$ & $\%$ \\
Lifestyle change (no addictions) & 31 & 29.81 \\
Diet & 50 & 48.08 \\
Regular and correct medication & 36 & 34.62 \\
$\begin{array}{l}\text { Systematic medical checks and } \\
\text { self-monitoring }\end{array}$ & 23 & 22.12 \\
Contact with medical staff & 25 & 24.04 \\
$\begin{array}{l}\text { Limitations of physical exertion } \\
\text { and sport activity }\end{array}$ & 50 & 48.08 \\
Restrictions to social contact & 8 & 7.69 \\
Fear of death & 38 & 36.54 \\
Fear of a sudden attack of the disease & 64 & 61.54 \\
and unexpected hospitalization & & \\
Limitations of professional work & 35 & 33.65 \\
\hline Fear of dependence on other people & 16 & 15.38 \\
Physical pain & 6 & 5.77 \\
\hline $\begin{array}{l}\text { Depressed mood resulting from } \\
\text { the disease }\end{array}$ & 53 & 50.96 \\
Chronic fatigue & 59 & 56.73 \\
Frequent hospital stays & 3 & 2.88 \\
Dyspnoea & 30 & 28.85 \\
\hline $\begin{array}{l}\text { Lack of psychological support during } \\
\text { hospitalization }\end{array}$ & 53 & 50.96 \\
Fear of surgery & 6 & 5.77 \\
\hline
\end{tabular}

Table 3. Levels of stress in the examined group

\begin{tabular}{|lccc|}
\hline PSS10 [points] & Interpretation & $\boldsymbol{N}$ & $\%$ \\
0-13 & Low level of stress & 4 & 3.85 \\
$14-19$ & Average level of stress & 7 & 6.73 \\
Up to 19 & High level of stress & 93 & 89.42 \\
\hline
\end{tabular}

Of the 104 patients, 93 (89.42\%) declared high levels of stress, 7 (6.73\%) declared medium levels, and $4(3.85 \%)$ declared low levels. These values are presented in Table 3. Stress levels were higher in the group with higher education ( $p=0.005)$, in the group with employment $(p=0.025)$, and in those with coexisting diseases $(p=0.038)$. The above relationships are presented in Table 4.

Spearman correlation showed a statistically significant relationship between age and stress. A significant and negative correlation was noted, which means that the older the age, the lower the level of stress $(p=0.011)$. The same correlation was found with respect to treatment time, i.e. the longer the therapy, the lower the stress level $(p=0.01)$. Considering the length of hospitalization, a significant and positive relationship was observed, i.e. the longer the hospitalization, the higher the stress level ( $p=0.021)$.

Variables such as gender, marital status, residence, manner of living, and main diagnosis did not determine stress levels $(p>0.05)$.

Sixty out of 104 (57.69\%) survey participants were prone to pessimism, 33 (31.73\%) respondents were neutral, and $11(10.58 \%)$ respondents were prone to optimism (Table 5). The highest values were obtained in the following statements: "It's important for me to keep busy" (3.3 \pm 0.89$)$, "If something can go wrong for

Table 4. Level of stress versus education, employment, and comorbidities

\begin{tabular}{|c|c|c|c|}
\hline PSS10 & $\begin{array}{l}\text { Primary, secondary, technical education } \\
\qquad(N=80)\end{array}$ & $\begin{array}{l}\text { Higher education } \\
\qquad(N=24)\end{array}$ & $P$-value \\
\hline Mean \pm SD & $22.12 \pm 4.27$ & $25.08 \pm 3.76$ & 0.005 \\
\hline Median & 21 & 26 & \\
\hline Quartiles & $20-25.25$ & $21-26.25$ & \\
\hline PSS10 & Employment $(N=24)$ & Pension/disability pension $(N=80)$ & $P$-value \\
\hline Mean \pm SD & $24.46 \pm 3.22$ & $22.31 \pm 4.51$ & 0.025 \\
\hline Median & 25.5 & 21.0 & \\
\hline Quartiles & $21-26$ & $20-26$ & \\
\hline PSS10 & Comorbidities $(N=40)$ & No comorbidities $(N=64)$ & $P$-value \\
\hline Mean \pm SD & $23.95 \pm 4.75$ & $22.09 \pm 3.91$ & 0.038 \\
\hline Median & 25 & 21 & \\
\hline Quartiles & $21-27$ & $21-25.25$ & \\
\hline
\end{tabular}

$p$-Mann-Whitney test. 
me, it will" (2.87 \pm 0.56$)$, and "I enjoy my friends a lot" $(2.77 \pm 1.01)$, which suggests that patients in the study group gave rather positive answers to this statement, i.e. "it rather refers to me" and/or "it definitely refers to me". This means that in these statements, the level of dispositional optimism is highest. The statements "It's easy for me to relax" $(1.7 \pm 1.3)$ and "I don't get upset too easily" (1.41 \pm 1.32$)$ obtained the lowest mean values, which means that most people indicated $r$ that they rather disagree with the above statements, i.e. "it definitely does not refer to me" and/or "it rather does not refer to me". This suggests that in these domains the treated patients showed the highest level of pessimism. These data are presented in detail in Table 6 .

The further part of the study includes the influence of variables such as the following: gender, age, manner of residence, education, place of residence, duration of disease, occurrence of coexisting diseases, and length of hospitalization, on the level of dispositional optimism index according to LOT-R. The comparison of the values of quantitative variables in 2 groups was performed using the Mann-Whitney $U$ test. It was shown that the level of dispositional optimism is statistically significantly influenced by the way of living ( $p=0.033)$. In the group of people living with a family, the LOT-R score was higher (life orientation was more positive). Correlations between quantitative variables were analysed using Spearman correlation coefficient. A significant and negative correlation was found in relation to the length of treatment, i.e. the longer the hospitalization, the lower the LOT-R score and, at the same time, the more pessimistic the life orientation ( $p=0.005)$. The level of dispositional optimism is not affected by gender, age, marital status, education, employment, residence, number of hospitalizations, main diagnosis, coexisting diseases, and length of treatment $(p>0.05)$.

In order to get to know the overall picture of the issue discussed above, an analysis of the sample was performed not only from the level of 2 characteristics, i.e. the level of stress severity (PSS-10) and the level of dispositional optimism (LOT-R), but also it was ascertained whether they are related to each other. The Pearson's linear correlation coefficient was used for this analysis. A significant and negative correlation was shown, i.e. the higher the stress level, the more pessimistic the orientation, and conversely, the lower the stress level, the higher the level of dispositional optimism $(p<0.001)$.

\section{Discussion}

The paper presents an analysis of the relationship between optimism and stress levels in patients hospitalized in cardiac wards. The way the patient functions depends not only on the treatment undertaken, but also on the level of stress intensity, coping with the disease, and attitudes towards it. The phenomenon
Table 5. The level of optimism in the studied group

\begin{tabular}{|lllc|}
\hline $\begin{array}{l}\text { LOT-R [points] } \\
0-12\end{array}$ & $\begin{array}{c}\text { Interpretation } \\
\text { A tendency }\end{array}$ & $\mathbf{N}$ & $\%$ \\
\hline $13-16$ & $\begin{array}{c}\text { to pessimism } \\
\text { Neutral } \\
17-24\end{array}$ & 33 & 31.73 \\
& $\begin{array}{c}\text { orientation } \\
\text { A tendency } \\
\text { to optimism }\end{array}$ & 11 & 10.58 \\
\hline
\end{tabular}

Table 6. Descriptive statistics for LOT-R

\begin{tabular}{|lcc|}
\hline Item & Mean & SD \\
$\begin{array}{l}\text { In uncertain times, I usually expect } \\
\text { the best }\end{array}$ & 2.02 & 1.06 \\
It's easy for me to relax & 1.7 & 1.3 \\
If something can go wrong for me, it will & 2.87 & 0.56 \\
I'm always optimistic about my future & 2.18 & 1.11 \\
I enjoy my friends a lot & 2.77 & 1.01 \\
It's important for me to keep busy & 3.3 & 0.89 \\
I hardly ever expect things to go my way & 2.13 & 0.92 \\
I don't get upset too easily & 1.41 & 1.32 \\
$\begin{array}{l}\text { I rarely count on good things } \\
\text { happening to me }\end{array}$ & 2.08 & 0.95 \\
$\begin{array}{l}\text { Overall, I expect more good things } \\
\text { to happen to me than bad }\end{array}$ & 2.06 & 0.81 \\
\hline
\end{tabular}

of stress is therefore one of the most frequently analysed variables in cardiology studies. The occurrence of cardiovascular diseases is often associated with the way and intensity of experiencing emotions caused by stress, which can trigger reactions even on the borderline of functioning and imbalance of the body.

The majority of patients in all age groups demonstrated a high intensity of stress. Similar data were obtained by the authors in patients with arterial hypertension [15], who were undergoing coronary angiography [16], and in men after heart attack [11]. However, lower stress levels were observed in patients undergoing percutaneous coronary interventions [17]. According to the literature, before procedures, women experienced higher levels of stress than men [18]. However, this cannot be confirmed by the analysis of our findings. Gender was a variable that did not determine the level of stress intensity.

Some authors report that the level of stress intensity increases with age, and its highest intensity was declared by patients over 65 years of age [19]. In this study, however, the opposite trend was observed, i.e. the level of perceived stress decreases with age, which is also consistent with the results of other authors. Therefore, the data are inconsistent and require further verification. 
Because stress and coping with chronic disease is a fairly common issue, it was decided to look at this phenomenon from a wider perspective, including patients treated in other wards. In our own study, 93 out of 104 patients declared high levels of stress (above 19 points). An equally high rate was reported in women with gynaecological cancer $(21.0 \pm 5.76)$ [20], women with menopause $(20.80 \pm 7.40)$ [11], patients with intestinal hypersensitivity syndrome (21.20 \pm 7.24$)$, with reflux disease $(20.77 \pm 7.12)$, with psoriasis (19.87 $\pm 5.14)$, and patients with rosacea (19.83 \pm 6.09$)$ [21]. A slightly lower result was found in dialysis patients (16.87 \pm 5.55$)$ [11]. Interestingly, in this study it was noted that the main diagnosis did not determine the severity of stress. Thus, it may confirm that the disease itself is such a strong experience that high stress levels persist regardless of its type, severity, and even course.

Dispositional optimism is one of the resources that helps to take constructive action in dealing with stress. As Dobrowolska [22] notes, people who are optimistic about life, who accept the disease, and are able to find positive sides in the situation of the disease cope better with its physical and psychological consequences. The importance of an optimistic approach to the disease was also emphasized by Simonton et al. [23], according to whom a positive attitude towards treatment is even a better predictor of the effectiveness of therapy than the disease severity. Moreover, Carver et al. [24] demonstrated that the higher the level of optimism in patients with early-stage breast cancer, the lower the stress they feel in further stages of treatment. The high level of optimism of these patients also proved to be a predictor of successful effects of anticancer therapy. The beneficial effect of optimism is also confirmed by the studies of Oginska-Bulik and Juczyński [25] in a group of women after mastectomy. Tallman et al. [26] noted that a high level of patients' optimism before bone marrow transplantation is a predictor of low depression and better physical functioning 1 year after transplantation. The optimism is also significantly related to the sense of "fighting spirit", positive revaluation [26], higher self-esteem, and greater self-efficacy in coping with the disease [27].

Being optimistic is particularly associated with benefits in cardiovascular diseases. Persons with positive attitudes have significantly lower blood pressure values [8], recover faster, suffer less frequently from heart diseases, and have lower risk of sudden and adverse cardiovascular events [28, 29]. Moreover, optimists are characterized by lower risk of clots and repeated myocardial infarction [8]. Moreover, studies have shown that after acute coronary syndrome, optimism was also associated with better mental and physical health and lower re-hospitalization [28].

However, this study showed that as many as 60 out of 104 treated patients had a tendency for pessimism, and only 11 of them declared a positive attitude towards treatment and hospitalization. The results ob- tained did not show any statistically significant difference in the level of dispositional optimism between men and women. This is consistent with the results of other authors. However, they state that a higher level of optimism in men than in women may appear during in-depth analyses in the context of work or private life [29]. The level of optimism was also not determined by age. However, such a correlation was observed in the studies by Łatka et al. [7], in which positive attitudes decreased in people over 60 years of age. The same authors report that the level of dispositional optimism is also correlated with education. The higher the level, the more positive the attitude and perception of reality related to the disease. However, this has not been confirmed in this paper, where no such correlation has been noted.

The relationships between stress and the level of dispositional optimism discussed in this paper are consistent with the general assumption about the positive impact of an individual's coping resources. Therefore, the importance of strengthening and shaping the sense of optimism through psychological interventions and all kinds of support using coping resources in difficult situations should be stressed. This seems to be crucial for several reasons. Firstly, Rief et al. [30] explicitly stated that the intervention focused on optimism in patients after heart surgery led to greater improvement of disability and their quality of life 6 months later. Similar results were achieved by Mohammadi et al. [9] in patients treated for heart failure. Secondly, in the present study, more than half of the patients declared their fear of relapse or hospitalization and decreased mood resulting from the disease, thus maintaining pessimistic tendencies. Thirdly, the involvement of a psychologist in the ward's work may have positive effects on medical results not only in terms of shaping optimistic attitudes towards the disease, but also by reducing the level of stress and by developing constructive coping strategies. Moreover, optimism is also associated with a beneficial effect on health behaviours, e.g. undertaking physical activity, modifying the diet, or quitting smoking, which is also associated with a lower percentage of adverse cardiac events [7].

Given that the higher the level of stress, the higher the pessimistic orientation, the implementation and use of such actions seems crucial. Therefore, it is still necessary to expand the knowledge in this context. This will allow for better understanding of the functioning of treated patients and will improve their comfort and quality of life. Future research on the use and application in clinical practice of such interventions may not only provide beneficial medical outcomes but also may lead to greater prevention and benefit public health in a broadly defined and understood sense.

This study had several limitations. First of all, a relatively small sample of 104 examined patients limits the representativeness of the results and the statistical power of the analyses obtained. Secondly, 
it was carried out in a relatively short period of time. However, the fact that data partly confirms previous results obtained in other hospitals in patients with both heart disease and other chronic diseases allows us to assume that data may also be reliable. Another potential limitation of this work is that, in light of the literature, optimism does not yet meet the epidemiological standards required to unequivocally identify it as an independent protective factor for clinical outcomes in patients with diagnosed heart disease [9].

The strengths of this study include primarily random group selection and the use of standardized questionnaires, which allow us to compare this study with others using the same tools.

\section{Conclusions}

Most patients declared high levels of stress. Factors such as education, employment, and comorbidities had a statistically significant impact on the level of stress severity in patients treated in cardiology departments. The older the age and the longer the treatment, the lower the stress level. The longer the hospitalization, the higher the stress level. Most of the patients treated showed a tendency for pessimism. The way of living had a statistically significant influence on the level of available optimism. The longer the hospitalization, the more pessimistic the life orientation. The optimistic attitude depends on the level of stress. The higher the stress level, the more pessimistic the orientation.

\section{Acknowledgments}

Project financed under the program of the Minister of Science and Higher Education called "Regional Initiative of Excellence”, project no. 024/RID/2018/19, amount of financing 11,999,000 zł.

\section{Conflict of interest}

The author declares no conflict of interest.

\section{References}

1. World Health Organization. Cardiovascular diseases fact sheet 2017.

2. Alonzo A. The experience of chronic illness and post-traumatic stress disorder: the consequences of cumulative adversity. Soc Sci Med 2000; 50: 1475-1484.

3. Bradley SM, Rumsfeld JS. Depression and cardiovascular disease. Trends Cardiovasc Med 2015; 25: 614-622.

4. Scheier MF, Carver CS. Optimism, coping, and health: assessment and implications of generalized outcome expectancies. Health Psychol 1985; 4: 219-247.

5. Wrzesińska M, Opuchlik K, Kocur J. Ocena umiejscowienia kontroli zdrowia oraz poziomu poczucia własnej skuteczności i optymizmu u chorych na stwardnienie rozsiane. Post Psychiatr Neurol 2008; 17: 313-318.
6. Chida Y, Steptoe A. Positive psychological well-being and mortality: a quantitative review of prospective observational studies. Psychosom Med 2008; 70: 741-756.

7. Łatka J, Majda A, Pyrz B. Dispositional optimism and health behavior of patients with hypertensive disease. Probl Pielęg 2013; 21: 21-28.

8. Raikkonen K, Matthews KA, Flory JD, Owens NL, Nesselroade JR, Mc Clearn GE. Effects of optimism, pessimism and trait anxiety on ambulatory blood pressure and mood during everyday life. J Pers Soc Psychol 1999; 76: 104-113.

9. Mohammadi N, Aghayousefi A, Nikrahan GR, Adams CN, Alipour A, Sadeghi M, Roohafza H, Celano CM, Huffman JC. A randomized trial of an optimism training intervention in patients with heart disease. General Hospital Psychiatry 2018; 51: 46-53.

10. Cohen S, Kamarck T, Mermelstein R. A global measure of perceived stress. J Health Soc Behav 1983; 24: 386-396.

11. Juczyński Z, Ogińska-Bulik N. Narzędzia pomiaru stresu i radzenia sobie ze stresem. Pracownia Testów Psychologicznych, Warszawa 2009.

12. Scheier MF, Carver CS, Bridges MW. Distinguishing optimism from neuroticism (and trait anxiety, self-mastery, and self-esteem): a re-evaluation of the Life Orientation Test. J Personal Soc Psychol 1994; 67: 1063-1078.

13. Poprawa R, Juczyński Z. Adaptacja Testu Orientacji Życiowej LOT-R. In: Juczyński Z. NPPPZ-Narzędzia Pomiaru w Promocji i Psychologii Zdrowia. Wyd. 2. Pracownia Testów Psychologicznych, Warszawa 2009.

14. R Core Team (2019). R: A language and environment for statistical computing. R Foundation for Statistical Computing, Vienna, Austria. URL https://www.R-project.org/

15. Ślusarska B, Lalik S, Kulina D, Zarzycka D. The intensity of stress in patients with hypertension and its relationship to self-control of patients' treatment. Arterial Hypertens 2013; 17: 369-376.

16. Starczewska M, Kapuścińska K, Rybicka A, Stanisławska M, Grochans E. The influence of sociodemographic factors on the level of stress and stress-coping strategies of patients subjected to coronarography. Probl Pielęgn 2018; 26: 151-156.

17. Bryniarski L, Kawecka-Jaszcz K. Czy istnieją granice wieku w kardiologii interwencyjnej? Przezskórne interwencje wieńcowe u osób w podeszłym wieku. Gerontol Pol 2005; 13: 153-161.

18. Biesiak B, Włoszczak-Szubzda A. Ocena poziomu stresu u pacjentów przed badaniami diagnostycznymi. Aspekty Zdrowia i Choroby 2016; 2: 23-33.

19. Bączyk G, Talarska D, Szubert J. Przyczyny lęku przedoperacyjnego chorych leczonych chirurgicznie. Ann UMCS Sect D 2006; 60 (Supl. 16, 1): 152-156.

20. Kupcewicz E, Olewińska J, Pikus H, Jóźwik M. Coping with stress by women diagnosed with gynecologic cancer. J Pre-Clin Clin Res 2018; 12: 16-21.

21. Orzechowska A, Talarowska M, Zboralski K, Florkowski A, Gałecki P. Subjective evaluation of symptoms and effects of treatment and the intensity of the stress and anxiety levels among patients with selected diseases of the skin and gastrointestinal tract. Psychiatria Polska 2013; 2: 225-237.

22. Dobrowolska M. Selected psychological resources of patients with ovarian cancer and the severity of the side effects of chemotherapy. Psychoonkologia 2013; 2: 56-61. 
23. Simonton OC, Matthews-Simonton S, Creighton JL. Triumf życia - możesz mieć przewagę nad rakiem. Wydawnictwo Ravi, Łódź 2005.

24. Carver CS, Pozo C, Harris SD, Noriega V, Scheier MF, Robinson DS, Ketcham AS, Moffat Jr FL, Clark KC. How coping mediates the effect of optimism on distress. A study of women with early breast cancer. J Pers Soc Psychol 1993; 65: 375-390.

25. Ogińska-Bulik N, Juczyński Z. Osobowość, stres, zdrowie. Wyd. Difin, Warszawa 2010.

26. Tallman BA, Altmeier E, Garcia C. Finding benefit from cancer. J Counseling Psychol 2007; 54: 481-487.

27. Weber-Rajek M, Ciechanowska $K$, Mieszkowski J, Niespodziński B, Wycech M, Perzyńska A. Impact of mental health resources on the quality of life of patients after stroke. J Health Sci 2014; 4: 51-60.

28. Huffman JC, Beale EE, Celano CM, Beach SR, Belcher AM, Moore SV. Effects of optimism and gratitude on physical activity, biomarkers, and readmissions after an acute coronary syndrome: the gratitude research in acute coronary events study. Circ Cardiovasc Qual Outcomes 2016 9: 55-63.

29. Czapiński J. Optymiści i ryzykanci. Polskie paradoksy. In: Jak Polacy przegrywaja, jak Polacy wygrywaja? Drogosz M (ed.). Gdańskie Wydawnictwo Psychologiczne, Gdańsk 2005; 127-148.

30. Rief W, Shedden-Mora MC, Laferton JA, Auer C, Petrie KJ Salzmann S, Schedlowski M, Moosdorf R. Preoperative optimization of patient expectations improves long-term outcome in heart surgery patients: results of the randomized controlled PSY-HEART trial. BMC Med 2017; 15: 4

\section{Address for correspondence:}

\section{Katarzyna Białek}

Institute of Medical Sciences

Jan Kochanowski University

Collegium Medicum

Kielce, Poland

Phone: +48 512318732

E-mail: katarzynabialek@vp.pl 